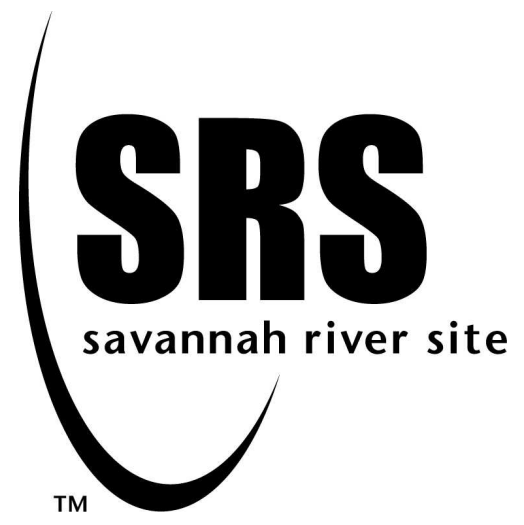

\title{
Effects of One Week Tritium Exposure on EPDM Elastomer
}

\author{
Elliot A. Clark
}

Publication Date: 7 June 2007

\section{Savannah River National Laboratory Washington Savannah River Company Savannah River Site Aiken, South Carolina}

This document was prepared in connection with work done under Contract No. DE-AC09-96SR18500 with the U.S. Department of Energy. By acceptance of this document, the publisher and/or recipient acknowledges the U.S. Government's right to retain a nonexclusive, royalty-free license in and to any copyright covering this document, along with the right to reproduce and authorize others to reproduce all or part of the copyrighted material.

WASHINGTON SAVANNAH RIVER COMPANY

The WSRC Team: Washington Savannah River Company LLC • Bechtel Savannah River, Inc. • BNG America Savannah River Corporation • BWXT Savannah River Company • CH2 Savannah River Company 


\section{DISCLAIMER}

This report was prepared as an account of work sponsored by an agency of the United States Government. Neither the United States Government nor any agency thereof, nor any of their employees, nor any of their contractors, subcontractors or their employees, makes any warranty, expressed or implied, or assumes any legal liability or responsibility for the accuracy, completeness, or any third party's use or the results of such use of any information, apparatus, product, or process disclosed, or represents that its use would not infringe privately owned rights. Reference herein to any specific commercial product, process, or service by trade name, trademark, manufacturer, or otherwise, does not necessarily constitute or imply its endorsement, recommendation, or favoring by the United States Government or any agency thereof or its contractors or subcontractors. The views and opinions of authors expressed herein do not necessarily state or reflect those of the United States Government or any agency thereof. 


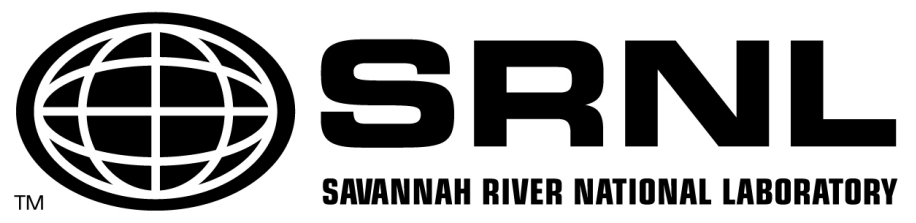

\title{
MATERIALS SCIENCE AND TECHNOLOGY
}

\section{Effects of One Week Tritium Exposure on EPDM Elastomer}

\author{
Elliot A. Clark \\ Materials Science and Technology
}

Savannah River National Laboratory, Aiken, South Carolina 29808 Washington Savannah River Company

Prepared for the U. S. Department of Energy under Contract DE-AC09-96SR18500 


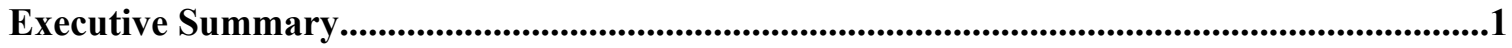

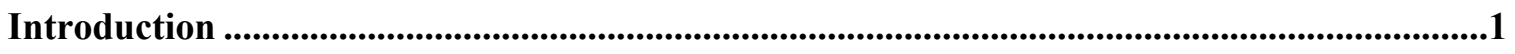

Exposure Program....................................................................................................................................1

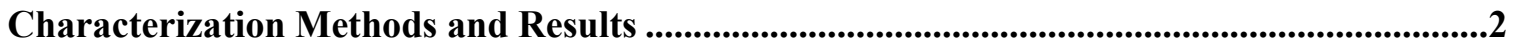

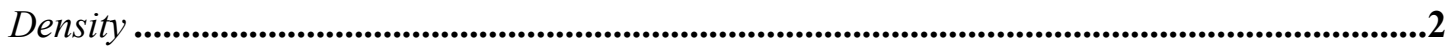

Visual Appearance ......................................................................................................................................3

Exposure Gas Pressure, Composition ............................................................................................................3

Bend Test for Sample Flexibility ................................................................................................................4

Dynamic Mechanical Analysis- Testing Details ..................................................................................4

Dynamic Mechanical Analysis- Results .................................................................................................5

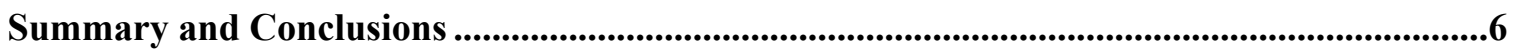

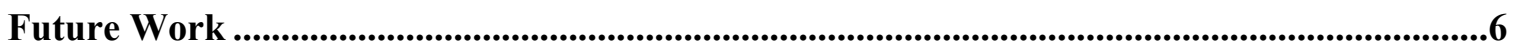

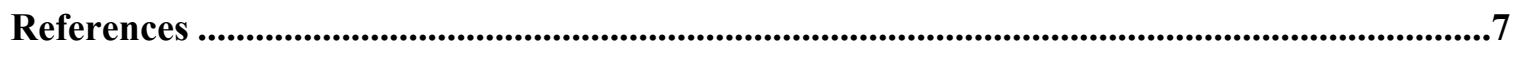

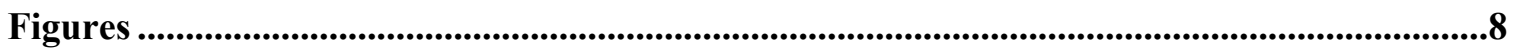




\section{TABLES}

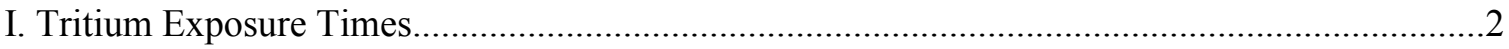

II. Initial, Final Gas Pressure and Change for Exposure Tests ......................................................

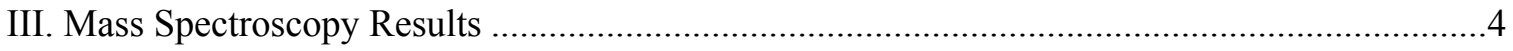

IV. Glass Transition Temperatures calculated using ASTM E 1640 and using the peak temperature of the loss modulus

\section{FIGURES}

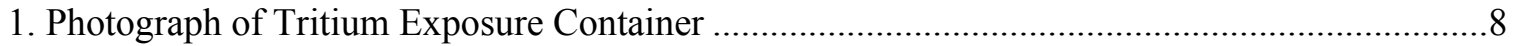

2. Sum of Sample Masses Before and After One Week Tritium Exposure.....................................9

3. Sum of Sample Volumes Before and After One Week Tritium Exposure.................................10

4. Density of Each Polymer Before and After One Week Tritium Exposure.................................11

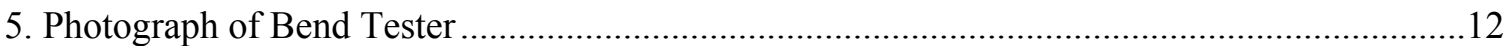

6. Storage modulus, loss modulus, and $\tan \delta$ of filled Nordel ${ }^{\mathrm{TM}}$ variation with amplitude at -

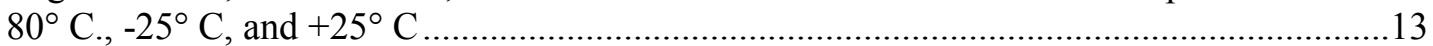

7. Storage modulus, loss modulus, tan delta for filled Nordel ${ }^{\mathrm{TM}}$.................................................14

8. Logarithm of storage modulus, loss modulus for filled Nordel ${ }^{\mathrm{TM}}$...........................................14

9. Storage modulus and loss modulus of filled Nordel with increasing temperature- two

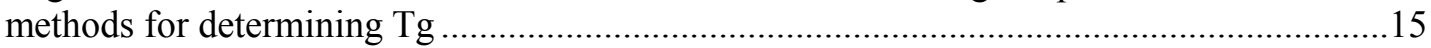




\section{Effects of One Week Tritium Exposure on EPDM Elastomer}

\section{EXECUTIVE SUMMARY}

This report documents test results for the exposure of four formulations of EPDM (ethylene-propylene diene monomer) elastomer to tritium gas at one atmosphere for approximately one week and characterization of material property changes and changes to the exposure gas during exposure. All EPDM samples were provided by Los Alamos National Laboratory (LANL). Material properties that were characterized include mass, sample dimensions, appearance, flexibility, and dynamic mechanical properties. The glass transition temperature was determined by analysis of the dynamic mechanical property data per ASTM standards.

No change of glass transition temperature due to the short tritium gas exposure was observed. Filled and unfilled formulations of Dupont ${ }^{\circledR}$ Nordel ${ }^{\mathrm{TM}} 1440$ had a slightly higher glass transition temperature than filled and unfilled formulations of Uniroyal ${ }^{\circledR}$ Royalene ${ }^{\circledR} 580 \mathrm{H}$; filled formulations had the same glass transition as unfilled.

The exposed samples appeared the same as before exposure- there was no evidence of discoloration, and no residue on stainless steel spacers contacting the samples during exposure was observed. The exposed samples remained flexible- all formulations passed a break test without failing.

\section{INTRODUCTION}

The unique properties of polymers make them ideal for certain components in gas handling systems. Specifically, the resiliency of elastomers is ideal for sealing surfaces, for example in valves. EPDM, initially developed in the 1960s, is a hydrocarbon polymer used extensively for sealing applications. EPDM is used for its excellent combination of properties including high/low-temperature resistance, radiation resistance, aging resistance, and good mechanical properties. This report summarizes initial work to characterize effects of tritium gas exposure on samples of four types of EPDM elastomer: graphite filled and unfilled formulations of Nordel $^{\mathrm{TM}} 1440$ and Royalene ${ }^{\circledR} 580 \mathrm{H}$.

\section{EXPOSURE PROGRAM}

Sheets of Nordel ${ }^{\mathrm{TM}} 1440$ and Royalene ${ }^{\circledR} 580 \mathrm{H}$ were obtained from LANL. Both standard graphite filled sheets and formulations synthesized without graphite at LANL were provided. The filled Nordel ${ }^{\mathrm{TM}}$ had a nominal thickness of $1.94 \mathrm{~mm}$, the filled Royalene ${ }^{\circledR} 5800.85 \mathrm{~mm}$, the unfilled Nordel ${ }^{\mathrm{TM}} 0.7 \mathrm{~mm}$ and the unfilled Royalene ${ }^{\circledR} 0.65 \mathrm{~mm}$. The filled polymers appeared black, and the unfilled versions appeared light grey. Rectangular slab-shaped samples having nominal lengths of $33 \mathrm{~mm}$ and nominal width of $9 \mathrm{~mm}$ were cut from the sheets.

Exposure containers were designed per ASME B31.3 and per Savannah River Site (SRS) Tritium Facility requirements. The design limits are maximum temperature of $500^{\circ} \mathrm{F}$ and maximum pressure of $500 \mathrm{psig}$. The containers (Fig. 1) are 3/4" by 0.049 tubing, about 8" long, connected to an adapter and then to a series of two bellows valves (Swagelok H-series). All wetted materials of the containers are Type 316 or Type 316L stainless steel.

Spacers were cut from $0.125 \mathrm{~mm}$ thick Type 316 stainless steel sheet. They were cut to be the same width as the samples $(9 \mathrm{~mm})$ and were $50 \mathrm{~mm}$ long. The two ends were bent around each sample to prevent the 
EPDM samples from contacting one other. Except for incidental contact with the spacers, the samples were not pressed or loaded during exposure.

Each exposure consisted of placing six samples in their spacers placed in one exposure container. After exposure, three samples were bend-tested; three were tested using Dynamic Mechanical Analysis (DMA). All six were weighed and dimensions measured before exposure. The containers were then attached to an experimental tritium gas system. The containers were evacuated overnight, and then tritium gas was admitted to 1 atmosphere pressure nominal. Both exposure container valves were closed and the samples were exposed to tritium for about one week (Table I.). The exposure temperature in all cases was the ambient temperature in the glovebox containing the gas system.

\begin{tabular}{|l|l|l|l|}
\hline Container Name & Material & Days Exposure & Exposure Temperature \\
\hline PC-1 & Filled Nordel & 11 & Ambient \\
\hline PC-2 & Filled Royalene & 7 & Ambient \\
\hline PC-3 & Unfilled Royalene & 7 & Ambient \\
\hline PC-4 & Unfilled Nordel & 7 & Ambient \\
\hline PC-5 & Filled Royalene & 7 & Ambient \\
\hline
\end{tabular}

Table I. $\quad$ Tritium Exposure Times

At the end of exposure, the pressure in the closed containers was measured using a pressure transducer by expanding the container gas into known system volumes. A grab sample of gas was then taken for mass spectroscopy analysis of the gas composition. The containers were then evacuated for several days. The container was then was backfilled with argon to about 1 atmosphere and both valves were then closed. The container was then moved to a Dynamic Mechanical Analysis (DMA) facility to characterize the samples.

\section{CHARACTERIZATION METHODS AND RESULTS}

\section{Density}

Irradiation damage of polymers causes density changes that vary with the irradiation dose [2]. The density was found by measuring the mass and volume of each sample, both before and after tritium exposure. The density was calculated by dividing the total mass of the samples by the total volume of the samples.

The electronic scale used to measure sample masses before exposure read to $0.0001 \mathrm{~g}$, and that used to measure after exposure read to $0.001 \mathrm{~g}$. Except for the first filled Royalene ${ }^{\circledR}$ exposure, there was no significant mass change (Fig. 2). An additional exposure of two filled Royalene ${ }^{\circledR}$ samples, to confirm this observation, resulted in no significant mass change (Fig. 2). Whether the observed mass change of the first filled Royalene ${ }^{\circledR}$ exposure is real or an experimental artifact (e.g. Tare feature of scale) is unclear.

The volume of each sample was measured by measuring the length, width, and thickness of the rectangular slab samples using ruler and caliper as appropriate (Fig. 3). Except for a possible total volume reduction of unfilled Nordel ${ }^{\text {, }}$, no significant change of volume was observed (Fig. 3).

The density of each polymer was calculated by dividing the total mass (Fig.2) by the total volume (Fig. 3) of each set of samples before and after tritium exposure. There is a slight increase in density in all the samples with one week tritium exposure. There is uncertainty of the mass measurement of the initial filled Royalene ${ }^{\circledR}$ 
exposure, the extra filled Royalene ${ }^{\circledR}$ exposure resulted in a significantly reduced density increase (Fig. 4). The apparent density increase of unfilled Nordel ${ }^{\mathrm{TM}}$ stems mainly from its measured decrease in total volume.

\section{Visual Appearance}

There were no observed changes in visual appearance of any samples exposed to tritium. Also, no evidence of debris on or of discoloration of the spacers was observed.

\section{Exposure Gas Pressure, Composition}

Pressure changes and composition changes in the exposure gas after the exposure period were determined. Radiolytic gas production has been found to be a useful monitor of tritium effects on polymers in the past, and also measuring gas production in tritium applications is important to maintain gas purity in these systems.

Except for unfilled Nordel ${ }^{\mathrm{TM}}$, observed pressure changes were small (Table II). Operators believe that valve leaks contributed to the observed larger change in PC-4.

\begin{tabular}{|c|c|c|c|c|c|}
\hline Container & Material & Initial & final & Change (\%) & Notes \\
\hline$\overline{P \text { PC } 1}$ & filled Nordel ${ }^{\mathrm{TM}}$ & $\overline{14.73}$ & $\overline{15.85}$ & $7.6 \%$ & \\
\hline PC 3 & unfilled Royalene $®$ & 14.79 & 15.14 & $2.4 \%$ & \\
\hline $\mathrm{PC} 4$ & unfilled Nordel $^{\mathrm{TM}}$ & 14.79 & 20.49 & $38.5 \%$ & $\begin{array}{l}\text { System leaks may } \\
\text { account for } \\
\text { pressure rise }\end{array}$ \\
\hline PC 5 & filled Royalene $₫$ & 14.91 & 14.84 & $-0.4 \%$ & $\begin{array}{l}\text { Extra exposure- } \\
\text { no data for PC } 2\end{array}$ \\
\hline
\end{tabular}

Table II. Initial, Final Gas Pressure and Change for Exposure Tests.

Mass spectroscopy was performed by scanning a standard set of mass to charge ratios (Table III). In both cases, a significant amount of $\mathrm{H}_{2}$ and $\mathrm{HT}$ was found. Also, some water production was evident. 


\begin{tabular}{|c|c|c|c|c|}
\hline & & Conce & tration (Mole P & ercent) \\
\hline$\frac{\text { Mass/Charge }}{\text { Ratio }}$ & Species & $\frac{\text { Filled }}{\text { Nordel }^{\mathrm{TM}}}$ & $\frac{\frac{\text { Unfilled }}{\text { Nordel }{ }^{\mathrm{TM}} \text { and }}}{\text { Unfilled }}$ & $\begin{array}{l}\text { Filled } \\
\text { Royalene } ® \\
\end{array}$ \\
\hline 2 & $\mathrm{H} 2$ & 1.196 & 0.240 & 0.075 \\
\hline 3 & $3 \mathrm{He}$ & 0.449 & 0.518 & 0.671 \\
\hline 3 & $\mathrm{HD}$ & 0.036 & 0.005 & 0.013 \\
\hline 4 & $4 \mathrm{He}$ & 0.000 & 0.048 & 0.000 \\
\hline 4 & $\mathrm{HT}$ & 17.300 & 7.774 & 4.601 \\
\hline 5 & DT & 0.287 & 0.159 & 0.464 \\
\hline 6 & $\mathrm{~T} 2$ & 79.748 & 90.278 & 93.155 \\
\hline 14 & & 0.000 & 0.000 & 0.000 \\
\hline 15 & & 0.000 & 0.000 & 0.000 \\
\hline 16 & & 0.000 & 0.000 & 0.000 \\
\hline 18 & $\mathrm{H} 2 \mathrm{O}$ & 0.019 & 0.014 & 0.019 \\
\hline 19 & $\mathrm{HDO}$ & 0.082 & 0.024 & 0.015 \\
\hline 20 & HTO & 0.005 & 0.004 & 0.000 \\
\hline 20 & $\mathrm{D} 2 \mathrm{O}$ & 0.040 & 0.000 & 0.005 \\
\hline 21 & DTO & 0.315 & 0.379 & 0.406 \\
\hline 22 & T2O & 0.166 & 0.067 & 0.046 \\
\hline 24 & CT4 & 0.311 & 0.469 & 0.519 \\
\hline 28 & $\mathrm{~N} 2 / \mathrm{CO}$ & 0.029 & 0.021 & 0.008 \\
\hline 32 & & 0.000 & 0.000 & 0.000 \\
\hline 36 & & 0.000 & 0.000 & 0.000 \\
\hline 40 & & 0.000 & 0.000 & 0.000 \\
\hline 44 & $\mathrm{CO} 2$ & 0.017 & 0.000 & 0.002 \\
\hline Total & >>>>>> & 100.000 & 100.000 & 99.999 \\
\hline
\end{tabular}

Table III. Mass Spectroscopy Results for exposure gas after exposure period. Scans performed at the mass/charge ratios specified in left column.

\section{Bend Test for Sample Flexibility}

A small bench top vice was altered to facilitate performing bend tests per ASTM E 290 - 97a "Standard Test Methods for Bend Testing of Materials for Ductility" (Fig. 5). The test performed was a Semi-Guided test for thin material, Arrangement B. Three of the six samples for each material were tested; no loss of ductility was found for any of the samples. Ductility loss would mean reduced sealing capability for elastomer O-rings.

\section{Dynamic Mechanical Analysis- Testing Details}

Dynamic mechanical analysis measures the elastic and viscoelastic parameters related to small cyclic deformation of materials- storage modulus, loss modulus, and tan delta. The storage modulus is the constant relating the amount of elastic deformation to a given applied load. For sealing applications, the storage modulus must not be too high- the O-ring seals by deforming and contacting intimately with the metallic sealing surfaces. The loss modulus is a measure of the time-dependent deformation under a given load, and 
provides insight to the amount of molecular motion occurring at various temperatures. Tan delta is the ratio of the loss modulus to the storage modulus.

Two TA Instruments Model 2980 dynamic mechanical analyzers were used for this study. This is a forced oscillation, controlled (non-resonant), constant amplitude instrument. The single-cantilever-beam clamp, or sample holder, was used, being the clamp of choice for measuring the glass transition temperature of elastomers. The oscillation amplitude was 60 microns used for unexposed samples and 40 microns for exposes samples. A so-called "amplitude sweep" at several temperatures revealed a wide range of oscillation amplitude results in equivalent DMA parameter measurement (Fig. 6).

DMA data was taken using the DMA Multi-Frequency mode, at set frequencies of $1,3,10$, and $30 \mathrm{~Hz}$. The DMA continuously acquired data at each of the set frequencies in sequence during the increasing temperature scans. The sampling rate was set at $3.0 \mathrm{sec} /$ point, which specifies the time over which data is acquired for each set frequency.

Each DMA test involved stabilizing the temperature at $-70^{\circ} \mathrm{C}$. for 10 minutes and then increasing the sample temperature at $1^{\circ} \mathrm{C}$. per minute until $0^{\circ} \mathrm{C}$. The TA 2980 has both electrical resistance heating and cooling by evaporated cold nitrogen gas from a liquid nitrogen container called the Gas Cooling Accessory (GCA) which is a part of the DMA system. The control software enables optimized control of cooling and heating for a given temperature and heating rate. The system was regularly calibrated at least once a month. The low temperatures studied required dry argon to be used for the air bearing gas.

\section{Dynamic Mechanical Analysis- Results}

A typical plot of storage modulus, loss modulus, and tan delta reveals the frequency dependence of the elastic and viscoelastic properties (Figs.7, 8) for filled Nordel ${ }^{\mathrm{TM}}$.

One critical parameter or property for amorphous polymers and elastomers, particularly for low-temperature applications, is the glass transition temperature (Tg). The $\mathrm{Tg}$ value represents the molecular transition between rubbery and "glassy" behavior, usually characterized by a volume change. Tg is important in sealing applications because elastomers lack the resiliency at temperatures below Tg that allows them to form a good mechanical seal, and so elastomers are not useful for sealing at temperatures below Tg.

Tg can be determined by several methods, including differential scanning calorimetry (DSC), dilatometry, and DMA. There are at least two accepted methods for determining Tg from DMA data. ASTM E 1640 "Standard Test Method for Assignment of the Glass Transition Temperature by Dynamic Mechanical Analysis" uses the intersection of two tangents of the storage modulus versus temperature curve: the tangent of data below $\mathrm{Tg}$ and the tangent at the inflection point of the sigmoidally changing storage modulus with temperature in the middle of the glass transition. The temperature of the tangents intersection is regarded as being $\mathrm{Tg}$. In this case, the standard requires an applied frequency of $1 \mathrm{~Hz}$ and a temperature increase rate of $1^{\circ} \mathrm{C} /$ minute, which were used in these tests. (DMA data at 3,10, and $30 \mathrm{~Hz}$ were not used to measure $\mathrm{Tg}$.) Either the linear or logarithmic plots can be used for this construction. In this work the linear plot is used by the analysis software. The other accepted method is the peak temperature of the loss modulus [1]. Both methods are illustrated for the data in Fig. 9.

Table IV presents the calculated glass transition temperatures for all tests. The Royalene ${ }^{\circledR}$ formulations, both filled and unfilled, have a Tg lower than the Nordel ${ }^{\mathrm{TM}}$ formulations by about $2-3^{\circ} \mathrm{C}$.

There is no effect of one week tritium gas exposure on $\mathrm{Tg}$ for any material. The ASTM E 1640 method calculates a $\mathrm{Tg}$ lower than the loss modulus peak by about $6^{\circ} \mathrm{C}$. Finally, there is no significant effect of graphite filler on $\mathrm{Tg}$ for one week tritium exposure. 


\begin{tabular}{|c|c|c|c|}
\hline Sample & Exposure & $\begin{array}{l}\text { Tg } \\
\frac{\text { ASTM E 1640 }}{\text { (Storage modulus }} \\
\text { tangents intercept) }\end{array}$ & $\frac{\text { Loss Modulus }}{\text { Peak }}$ \\
\hline Nordel Filled & none & -52 & -44 \\
\hline "6 & 1 Week & -49 & -44 \\
\hline “" & 1 Week & -54 & -44 \\
\hline “" & 1 Week & -52 & -45 \\
\hline Royalene filled & none & -56 & -49 \\
\hline “" & 1 Week & -55 & -49 \\
\hline “" & 1 Week & -55 & -50 \\
\hline “" & 1 Week & -54 & -49 \\
\hline Nordel Unfilled & none & -52 & -46 \\
\hline " & 1 Week & -53 & -46 \\
\hline " & 1 Week & -53 & -46 \\
\hline "“ & 1 Week & -52 & -46 \\
\hline Royalene Unfilled & none & -55 & -49 \\
\hline "6 & 1 Week & -55 & -49 \\
\hline "6 & 1 Week & -55 & -49 \\
\hline "6 & 1 Week & -54 & -50 \\
\hline
\end{tabular}

Table IV. Glass Transition Temperature calculated using ASTM E 1640 and using the peak temperature of the loss modulus.

\section{SUMMARY and CONCLUSIONS}

Samples of filled and unfilled Nordel ${ }^{\mathrm{TM}} 1440$ and filled and unfilled Royalene ${ }^{\circledR}$ EPDM 580H elastomer were exposed to tritium gas at one atmosphere for about a week at ambient temperature. There were no changes in the appearance of the samples and no evidence of degradation or discoloration. The samples remained flexible. The glass transition temperature did not change, as measured by dynamic mechanical analysis. Mass changes observed for one set of samples were not observed in a separate exposure of the same material. Mass spectroscopy of the gas after exposure revealed significant amounts of $\mathrm{H}_{2}$ and $\mathrm{HT}\left({ }^{1} \mathrm{H}_{2}\right.$ and ${ }^{1} \mathrm{H}^{3} \mathrm{H}$ ), as well as lesser amounts of water and methane.

\section{FUTURE WORK}

Future tests will expose these four materials to tritium at ambient temperature and 1 atmosphere for one- , three-, six-, and twelve months. Material aging and gaseous radiolysis products will be characterized as in this report. If possible, other formulations of Royalene ${ }^{\circledR}$ having no additives and varying degrees of cross linking $(0 \%, 100 \%, 150 \%$ of the degree of cross linking used in the tests reported here) will also be exposed to tritium gas and their aging characterized. The tritium aging characteristics of a polymer sheet having the 
conductive polymer polyaniline incorporated would also be investigated. The electrical resistance of polyaniline sheet is being considered as a tritium sensor.

\section{REFERENCES}

1) "Mechanical Properties of Polymers and Composites", 2nd Ed., L.E. Nielsen, R.F. Landel, Marcel Dekker, Inc, New York (1994) p. 141.

2) "Radiation Chemistry of Polymeric Systems", A. Chapiro, Wiley- Interscience, New York (1962) p. 392.

\section{ACKNOWLEDGEMENTS}

It is a pleasure to acknowledge: Wanda Britt for sample characterization before testing, sample tracking and handling, mass and volume measurements, DMA operation, hood decontamination, waste management; Mike Thomas for DMA installation and facility interface; Kipp Neikirk for exposure container design and procurement; Greg Staack and Dante Pilgrim for tritium exposure and sample transport. 


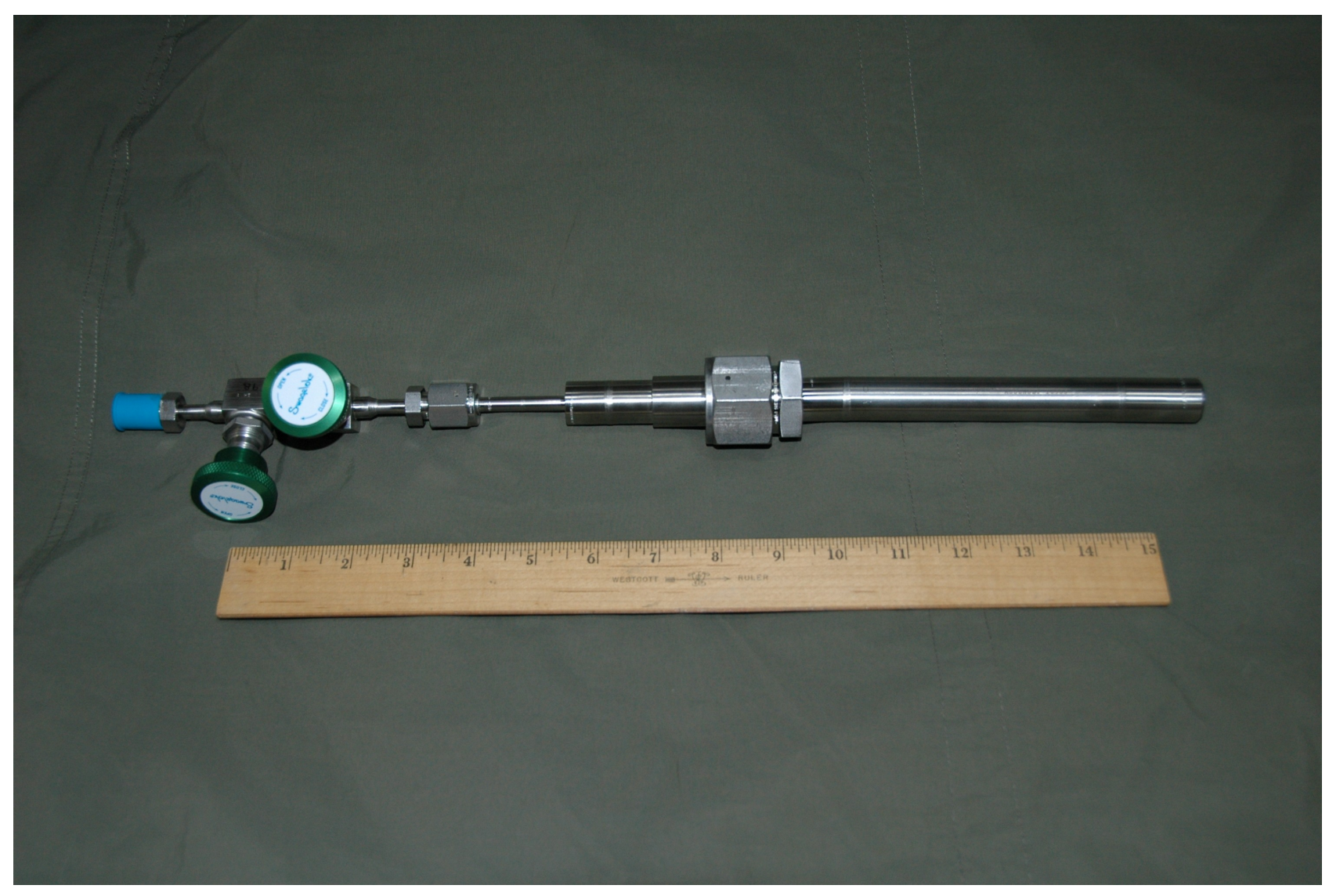

Page 8 of 15 
Figure 1. Photograph of Tritium Exposure Container.

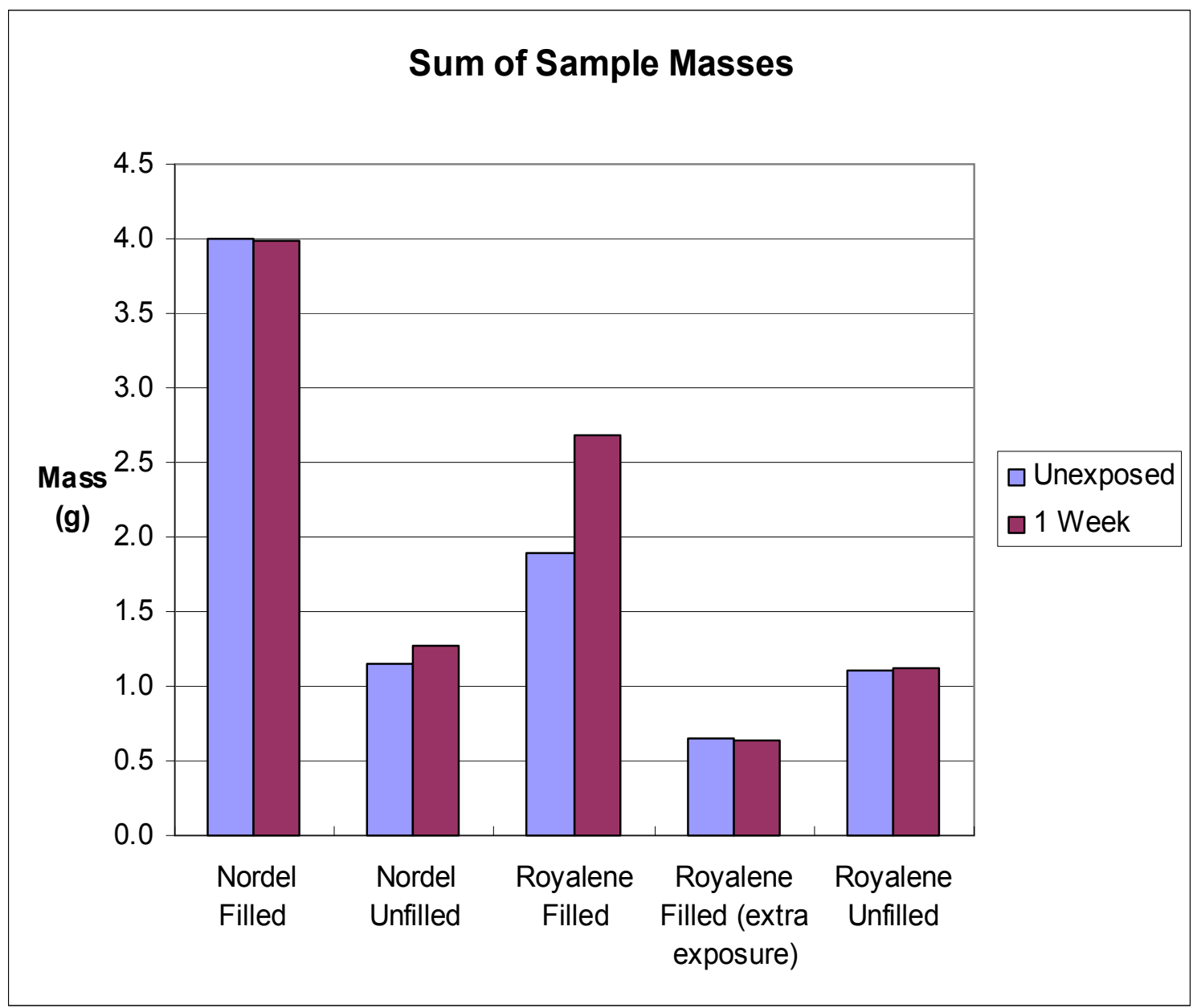

Figure 2. Sum of Sample Masses Before and After One Week Tritium Exposure. "Royalene ${ }^{\circledR}$ Filled (Extra Exposure)" consisted of two samples, all others consisted of six samples. Samples were not labeled, so sum of masses used. (Error bars of propagated mass measurement tolerance too small to view.) 


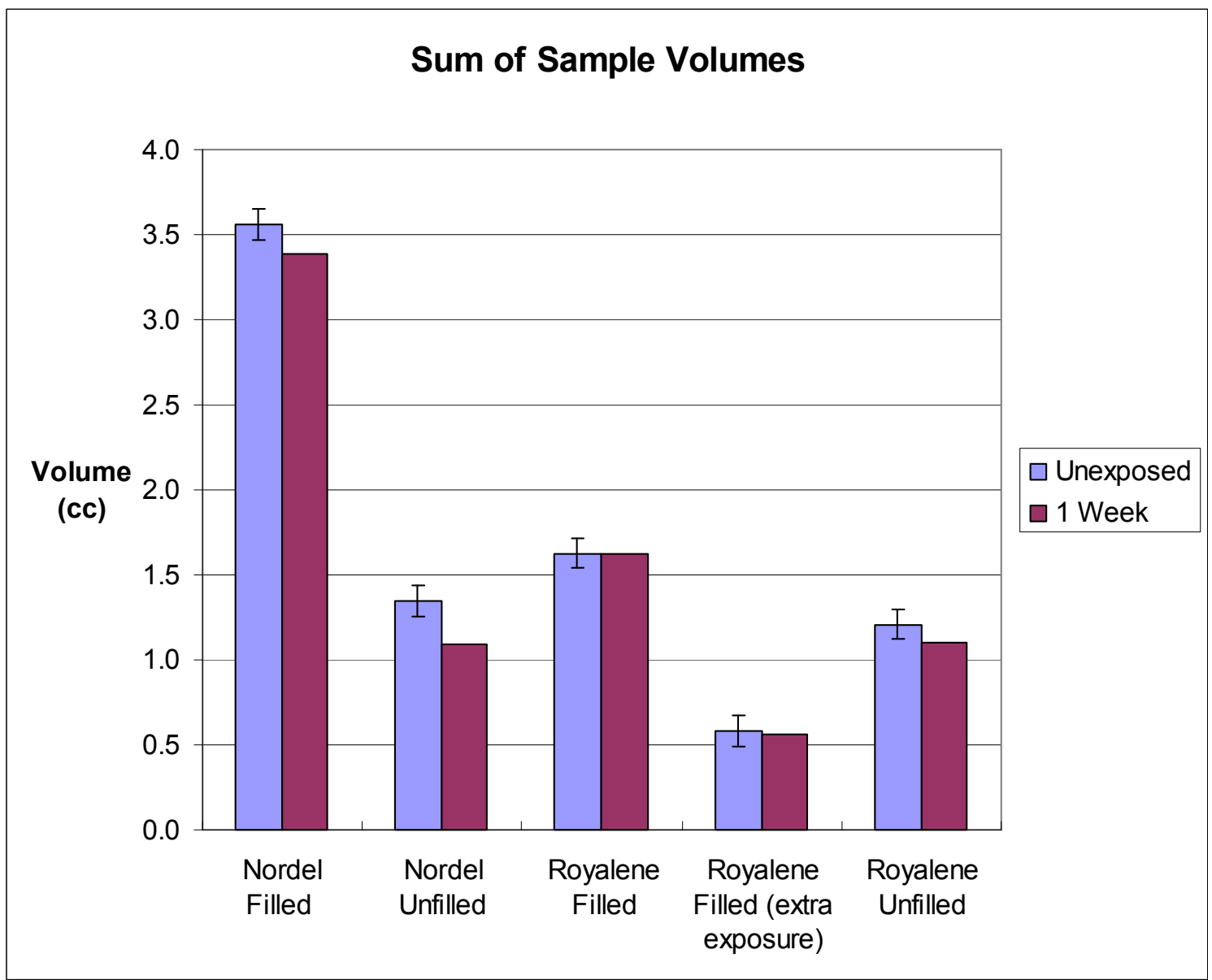

Figure 3. Sum of Sample Volumes Before and After One Week Tritium Exposure. "Royalene® Filled (Extra Exposure)" consisted of two samples; all others consisted of six samples. Samples were not labeled, so sum of volumes used. Error bars are propagated tolerance of individual dimension measurements through calculation of volume. 


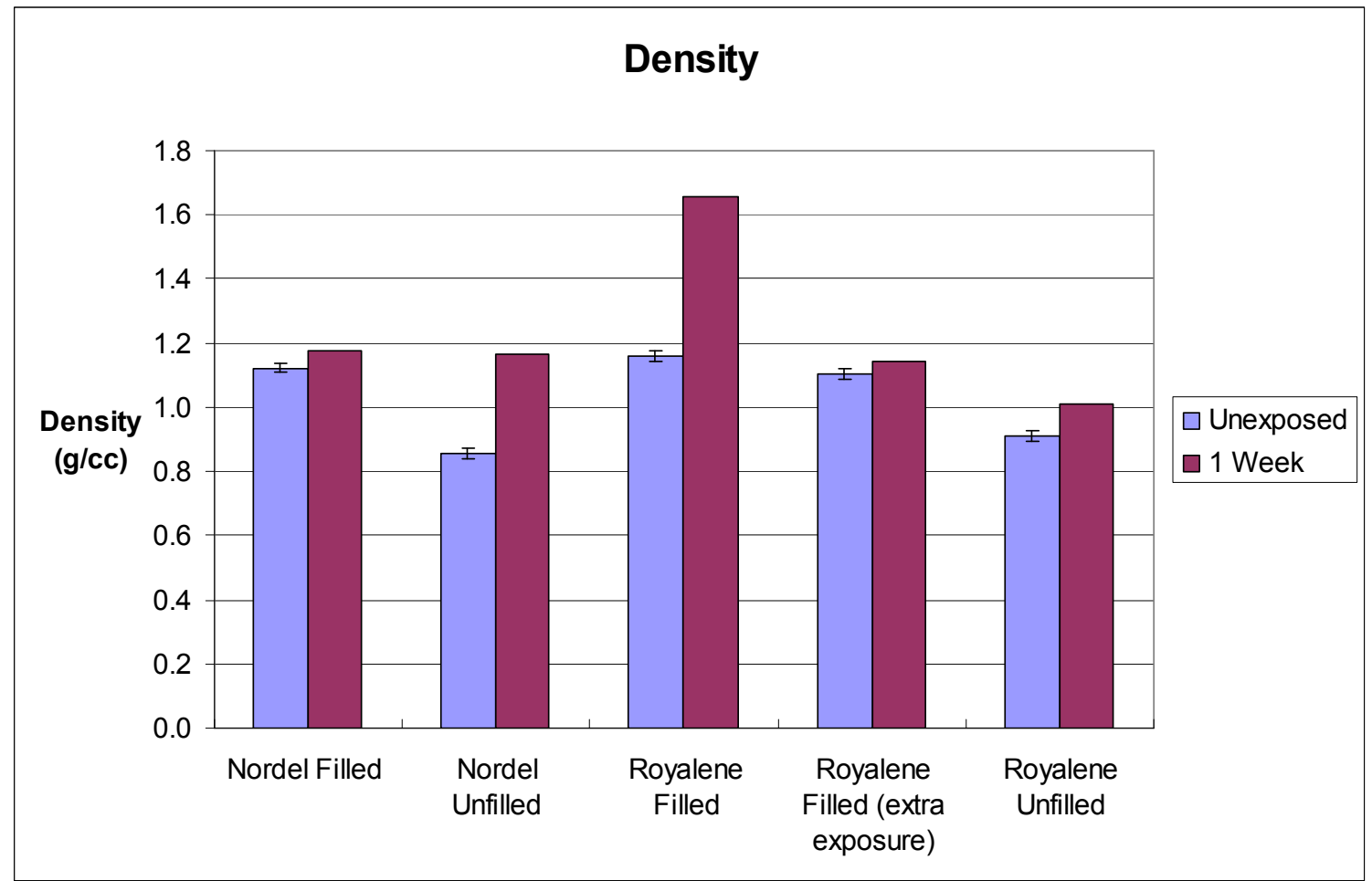

Figure 4. Density of Each Polymer Before and After One Week Tritium Exposure. Density calculated by dividing Total Mass (Fig. 2) by Total Volume (Fig. 3). 


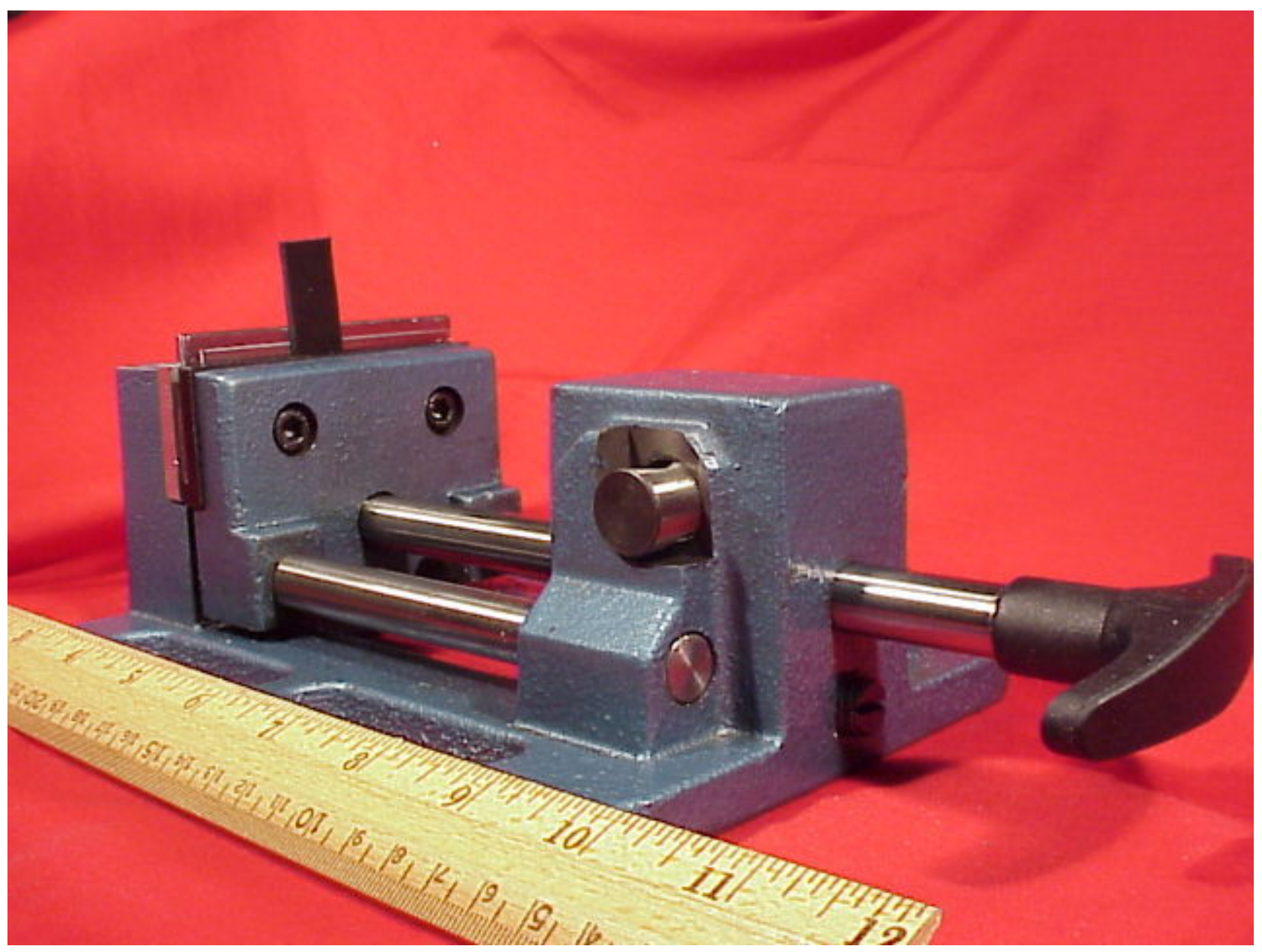

Figure 5. Photograph of Bend Tester, ASTM E 290 - 97a; Semi-Guided Bend, Thin Material. Note filled EPDM sample in position for bend. 


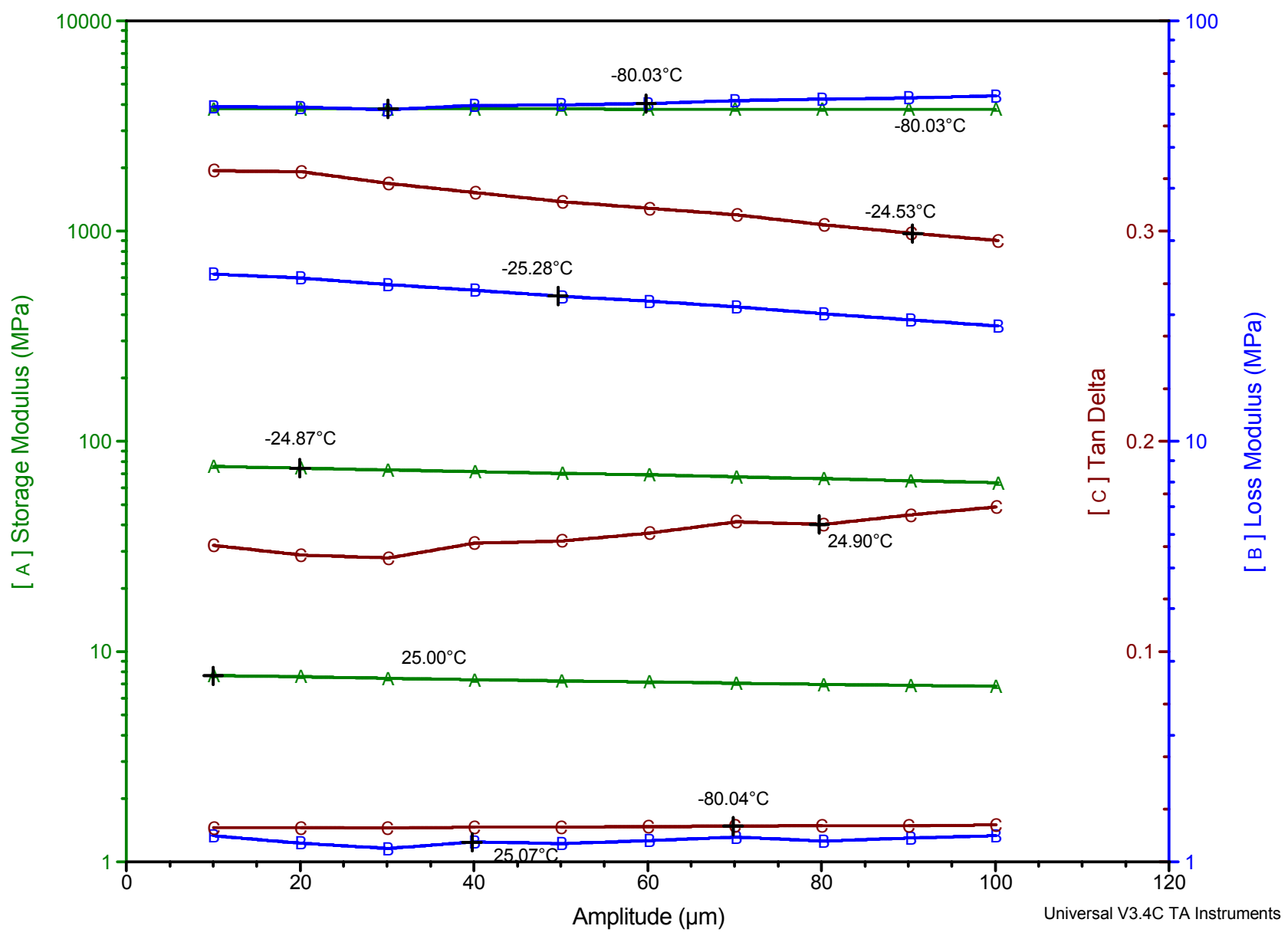

Figure 6. Storage modulus, loss modulus, and $\tan \delta$ of filled Nordel ${ }^{\mathrm{TM}}$ variation with amplitude at $-80^{\circ} \mathrm{C}$., $-25^{\circ} \mathrm{C}$, and $+25^{\circ} \mathrm{C}$. Little variation of elastic and viscoelastic parameters with amplitude at all temperatures tested. 


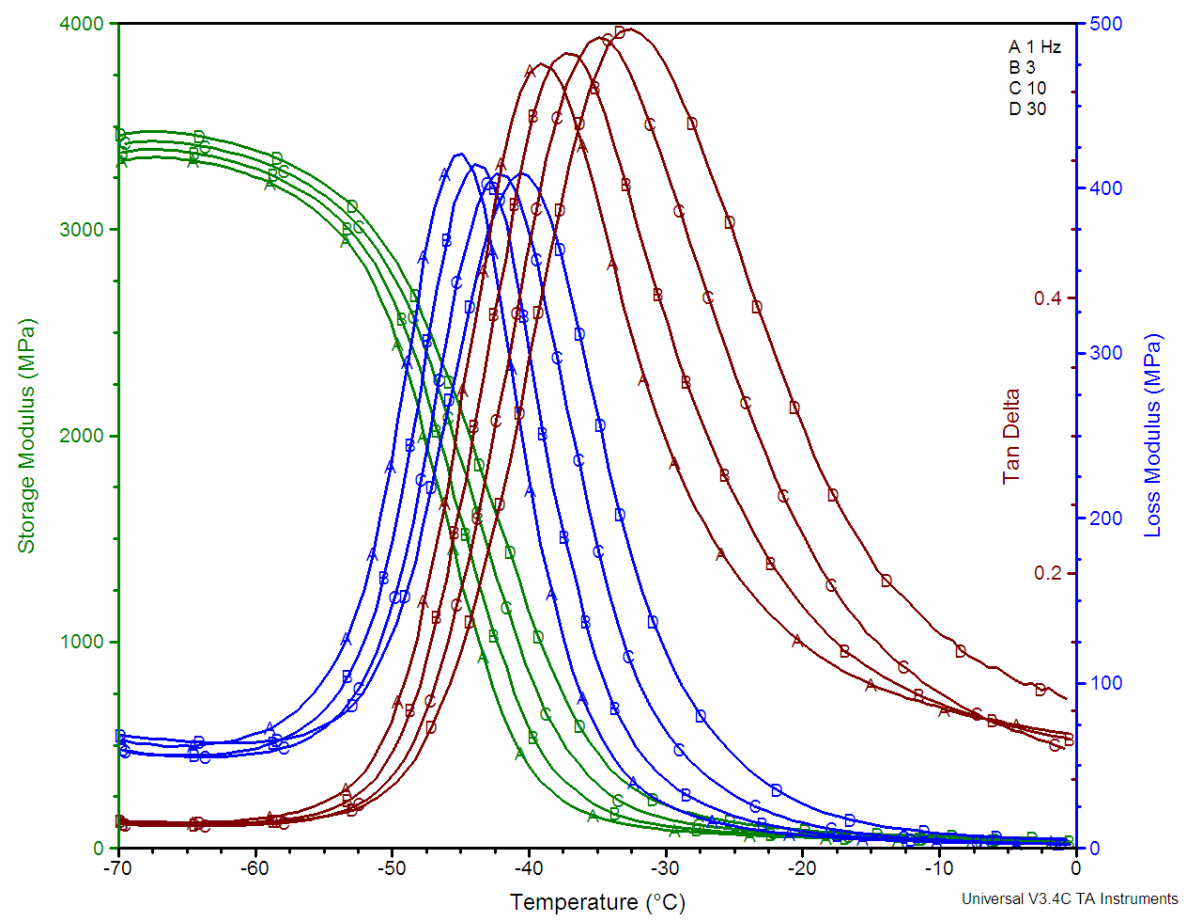

Figure 7. Storage modulus (green), loss modulus (blue), tan delta (brown) for filled Nordel ${ }^{\mathrm{TM}}$. Temperature increased at $1^{\circ} \mathrm{C}$. per minute, 40 microns amplitude. Letters denote test frequency as given in legend.

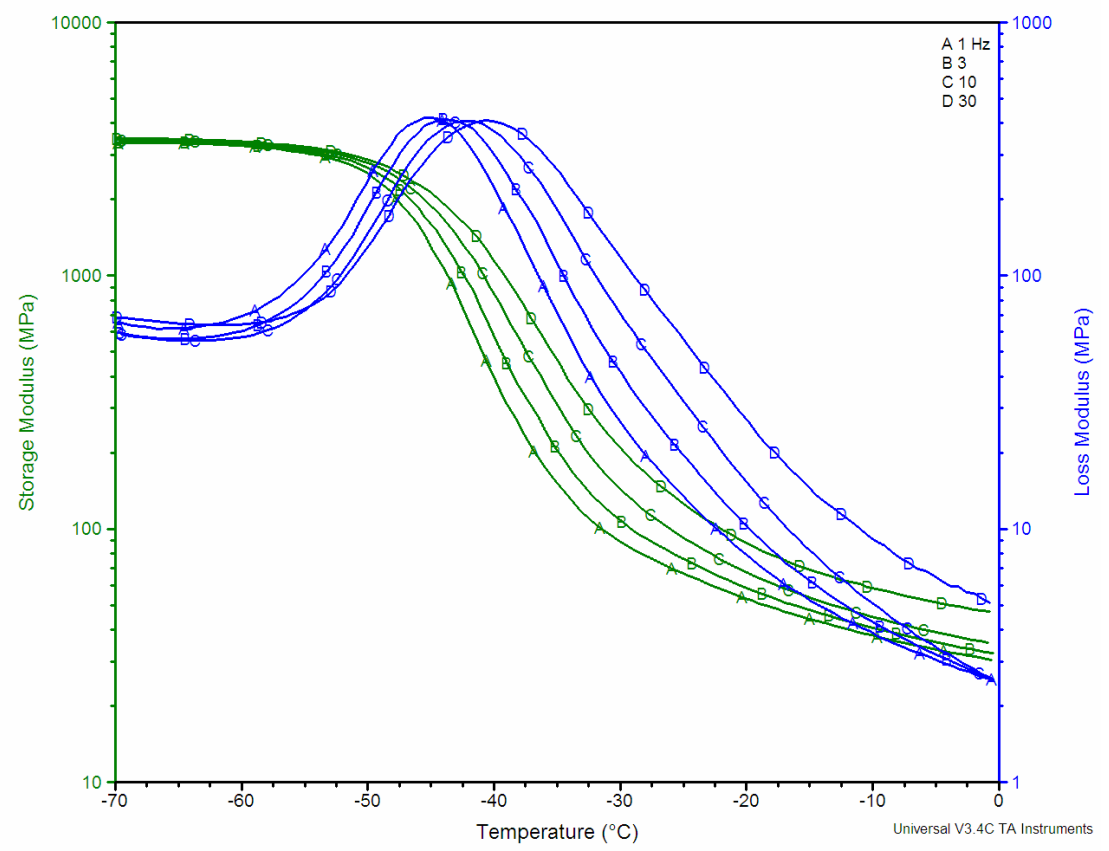

Figure 8. Logarithm of storage modulus (green), loss modulus (blue) for filled Nordel ${ }^{\mathrm{TM}}$ (same data as Fig. 7). 


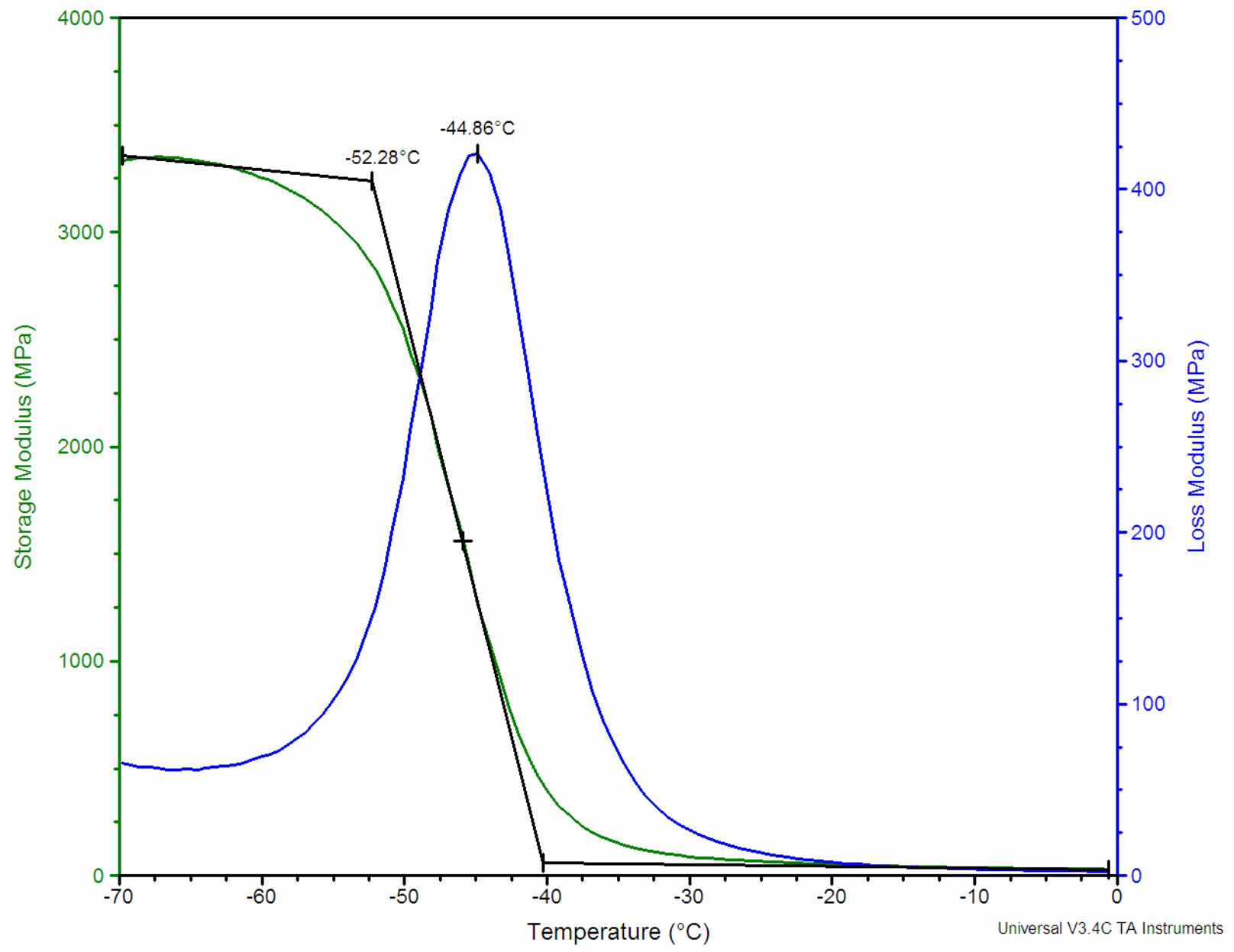

Figure 9. Storage modulus and loss modulus of filled Nordel ${ }^{\mathrm{TM}}$ with increasing temperature (data part of Figs. 7,8 ). ASTM E 1640 construction by DMA analysis software obtains $-52^{\circ} \mathrm{C}$. (tangent intersection), peak of loss modulus obtains $-45^{\circ} \mathrm{C} .1 \mathrm{~Hz}$ data, $1^{\circ} \mathrm{C} . /$ minute heating rate. 